\title{
On the Chinese species of Scaphobaeocera Csiki, 1909, and new records of Scaphoxium Löbl, 1979 and Toxidium LeConte, 1860 (Coleoptera: Staphylinidae: Scaphidiinae)
}

\author{
Виды Scaphobaeocera Csiki, 1909 Китая и новые находки видов \\ Scapboxium Löbl, 1979 и Toxidium LeConte, 1860 \\ (Coleoptera: Staphylinidae: Scaphidiinae)
}

\author{
Ivan Löbl \\ Иван $\Lambda \ddot{е ̈} \Lambda$
}

Museum d'histoire naturelle, route de Malagnou 1, CH-1208 Genève, Switzerland. E-mail: Ivan.lobl@bluewin.ch

KEY WORDS: Scaphidiinae, Scaphisomatini, taxonomy, new species, new records, China, high-altitude zones.

КЛЮЧЕВЫЕ СЛОВА: Scaphidiinae, Scaphisomatini, таксономия, новые виды, новые отметки, Китай, высокогорье.

ABSTRACT. Following new species of Scaphobaeocera Csiki, 1909 are described from Southern China, almost all from high-altitude sites: S. junlei sp.n., $S$. yunnana sp.n., S. glabra sp.n., S. michaeli sp.n., $S$. schuelkei sp.n., S. puetzi sp.n., and S. glabripennis sp.n. Scaphobaeocera nuda Löbl, 1979; Toxidium curtilineatum Champion, 1927 and T. robustum Pic, 1930 are for the first time reported from China, and new records are given for additional four species of Scaphobaeocera and one species of Scaphoxium. A key to the Chinese species of Scaphobaeocera is provided.

РЕЗЮМЕ. Из высокогорий Южного Китая описаны новые виды Scaphobaeocera Csiki, 1909: S. junlei sp.n., S. yunnana sp.n., S. glabra sp.n., S. michaeli sp.n., S. schuelkei sp.n., S. puetzi sp.n., and $S$. glabripennis sp.n. Scaphobaeocera nuda Löbl, 1979; Toxidium curtilineatum Champion, 1927 и T. robustum Pic, 1930 впервые приводятся для Китая, как и новые находки ещё четырёх видов Scaphobaeocera и одного - Scaphoxium. Приводится ключ видов Scaphobaeocera Китая.

\section{Introduction}

Several Scaphisomatini genera possess strongly narrowed metaventrite, correlated with approximate mesocoxae and metacoxae [Leschen, Löbl, 2005]. Only four of them are known from China: Scaphobaeocera Csiki, 1909, Scaphoxium Löbl, 1979, Toxidium LeConte, 1860, and Scaphicoma Motschulsky, 1863.
Among them, the species-rich genus Scaphobaeocera is with 102 species currently recognized as valid and distributed throughout subtropical and tropical Asia (including the transitional areas in Japan, Far East Russia and Pakistan), Melanesia, Australia, and Micronesia, and with five species also known from the Afrotropical realm including the Seychelles and Mascarene Islands [Löbl, 1997] and subsequent papers. Members of this genus may be easily found in samples of moist forest floor litter (pers. observation) and as far known feed on slime mould [e.g. Newton, Stephenson, 1990]. A review of the Chinese mainland Scaphobaeocera was given in Löbl [1999] and supplemented in Löbl [2003] while the Taiwanese species have been treated in Löbl [1980]. Löbl [1999, 2003] provided descriptions and/or records of 16 Chinese species, five of them possibly being endemic. Only three of these species have been reported from higher altitudes in China: S. cognata Löbl, 1984 sampled between 1500$2800 \mathrm{~m}$, S. difficilis Löbl, 1979 from 2000-2200 m, and S. spira Löbl, 1990, from 2200-2500 m above sea-level. Collections recently studied yield significant additional information, especially for the highaltitude species some of which have been collected above $3000 \mathrm{~m}$. Seven of these species are described below as new, and one is recorded for the first time from China. The newly examined collections contain also members of Scaphoxium and Toxidium that extend for several species the known range, and two of the species have not yet been reported from China. Therefore, the respective records are given also for members of these genera.

How to cite this article: Löbl I. 2018. On the Chinese species of Scaphobaeocera Csiki, 1909, and new records of Scaphoxium Löbl, 1979 and Toxidium LeConte, 1860 (Coleoptera: Staphylinidae: Scaphidiinae) // Russian Entomol. J. Vol.27. No.2. P.123-134. doi: 10.15298/rusentj.27.2.02 


\section{Material and methods}

The specimens studied are deposited in the following collections:

APPC — Private collection of Andreas Pütz, Eisenhüttenstadt, Germany.

MSPC — Private collection of Michael Schülke, Berlin, Germany.

MHNG — Muséum d'histoire naturelle, Geneva, Switzerland.

NMEC - Naturkundemuseum, Erfurt, Germany.

NMPC — National museum, Entomology Department, Praha, Czech Republic.

The locality data are reproduced verbatim. Data from different labels are separated by a slash. Adequate printed type- and/or identification labels are fixed under each examined specimen. The body length is measured from the anterior pronotal margin to the posterior inner angles of elytra. The length/width ratios of the antennomeres are measured on slide-mounted antennae. Statements about punctation on metaventrite and ventrite 1 do not refer to punctures margining subcoxal lines. The sides of the aedeagi refer to their morphological side with the ostium situated dorsally, while it is in resting position rotated $90^{\circ}$. The dissected body-parts are embedded in Euparal and fixed on a separate label on the same pine as the respective specimens.

Several species may be reliably distinguished only by their male genital characters. The respective records are based on males only, unless specified on females.

\section{Taxonomy}

\section{REVISED KEY TO THE CHINESE SPECIES OF SCAPHOBAEOCERA CSIKI}

1. Antennomere VII conspicuously large compared to VI and VIII, about 4 to 6 times as long as VIII, longer than antennomeres $\mathrm{V}$ and $\mathrm{VI}$ combined

- Antennomere VII less than 3 times as long as VIII, shorter than antennomeres $\mathrm{V}$ and VI combined

2. Antennomere VII about 6 times as long as wide, and 6 times as long as antennomere VIII......... S. fujiana Löbl, 2003

- Antennomere VII about 4 times as long as wide and 4 times as long as antennomere VIII

3. Apical process of median lobe long, tapering, with acute tip in lateral view; flagellum weakly bent. Metaventrite with median stria S. yunnana sp.n.

- Apical process of median lobe short, broad, with blunt tip; flagellum convoluted. Metaventrite without median stria S. junlei sp.n

4. Antennomere XI conspicuously elongate, about as long as antennomeres IX and X combined

- Antennomere XI moderately elongate, much shorter than antennomeres IX and X combined

5. Elytra microsculptured

- Elytra not microsculptured. Aedeagus with asymmetrical, narrow parameres .................................. S. glabra sp.n.

6. Aedeagus with symmetrical parameres ......................... 7

- Aedeagus with asymmetrical parameres .....

S. michaeli sp.n.

7. Middle part of parameres not widened in dorsal view; contour of median lobe broadly concave posterior level of parameral bases ........ S. dorsalis Löbl, 1980

- Middle part of parameres widened in dorsal view; contour of median lobe convex posterior level of parameral bases S. schuelkei sp.n.

8. Antennomere XI shorter, or as long, as antennomere X S. spinigera Löbl, 1979

Antennomere XI longer than antennomere X ............ 9

9. Elytra, pronotum and metaventrite not microsculptured

10

- Elytra, often also pronotum and metaventrite, microsculptured

10. Prevailing body surface black, scutellum concealed. Tip of median lobe acute (lateral view), gonostyle with long apical seta ............................................. S. puetzi sp.n.

- Body reddish-brown or ochreous, tip of scutellum exposed. Tip of median lobe blunt (lateral view), gonostyle with two short apical setae .......... S. glabripennis sp.n.

11. Hypomera with distinct longitudinal stria delimiting narrower upper surface from lower surface .................. 12

- Hypomera without longitudinal stria ......................... 13

12. Antennomere VIII about 4 times as long as wide. Bodylength $1.6 \mathrm{~mm}$................... S. pseudovalida Löbl, 1999

- Antennomere VIII less than 3 times as long as wide. Bodylength 1.2 to $1.3 \mathrm{~mm}$................ S. amicalis Löbl, 2003

13. Aedeagus with notched parameres S. incisa Löbl, 1990

- Aedeagus with not notched parameres ...................... 14

14. Aedeagus with median lobe extended to form prominent ventral plate posterior articular process ..... S. lamellifera Löbl, 1984

- Aedeagus with median lobe not forming prominent ventral plate ................................................................. 15

15. Aedeagus with flagellum simple, slightly bent and gradually narrowed ............................. S. simplex Löbl, 1999

- Aedeagus with flagellum different 16

16. Aedeagus with flagellum simple, sinuate, evenly wide . S. nuda Löbl, 1979

- Aedeagus with flagellum different ............................. 17

17. Aedeagus with flagellum spiral and simple ............. 18

- Aedeagus with flagellum not spiral, or spiral with complex proximal section

18. Aedeagus with flagellum forming two or three complete circles ....................................... S. difficilis Löbl, 1979

- Aedeagus with flagellum forming six or seven complete circles ............................................. S. spira Löbl, 1990

19. Basal bulb of aedeagus prominent apicoventrally ... S. nobilis Löbl, 1984

- Basal bulb of aedeagus not prominent apicoventrally 20

20 . Aedeagus with parameres conspicuously widened in apical third (lateral view), flagellum spiral, with large and complex base ............................. S. molesta Löbl, 1999

- Aedeagus with parameres moderately widened in two apical thirds (lateral view), flagellum not spiral, with small, hook-like base ................ S. cognata Löbl, 1984

\section{Scaphobaeocera junlei Löbl sp.n.}

Figs 2, 6, 12-14.

MATERIAL EXAMINED. Holotype $0^{r}$ : CHINA: Yunnan [CH07-14] Baoshan Pref., Gaoligong Shan, 33 km SE Tongchong, 2100-2200 m, 24⒌ $51^{\prime} 23^{\prime} \mathrm{N}$ 98 $45^{\circ} 35^{\prime}$ 'E, deciduous forest, litter, wood, fungi sifted, 31.V.2007, M. Schülke (MSPC).

Paratypes: $8 \sigma^{7}, 2$, with the same data as the holotype (MSPC, MHNG).

DESCRIPTION. Length $1.55-1.70 \mathrm{~mm}$, width 0.90 $1.03 \mathrm{~mm}$, dorsoventral diameter $0.87-1.0 \mathrm{~mm}$. Head and most of body black or very dark with reddish shine. Abdomen blackish-brown. Antennomeres I to IV yellowish, following 


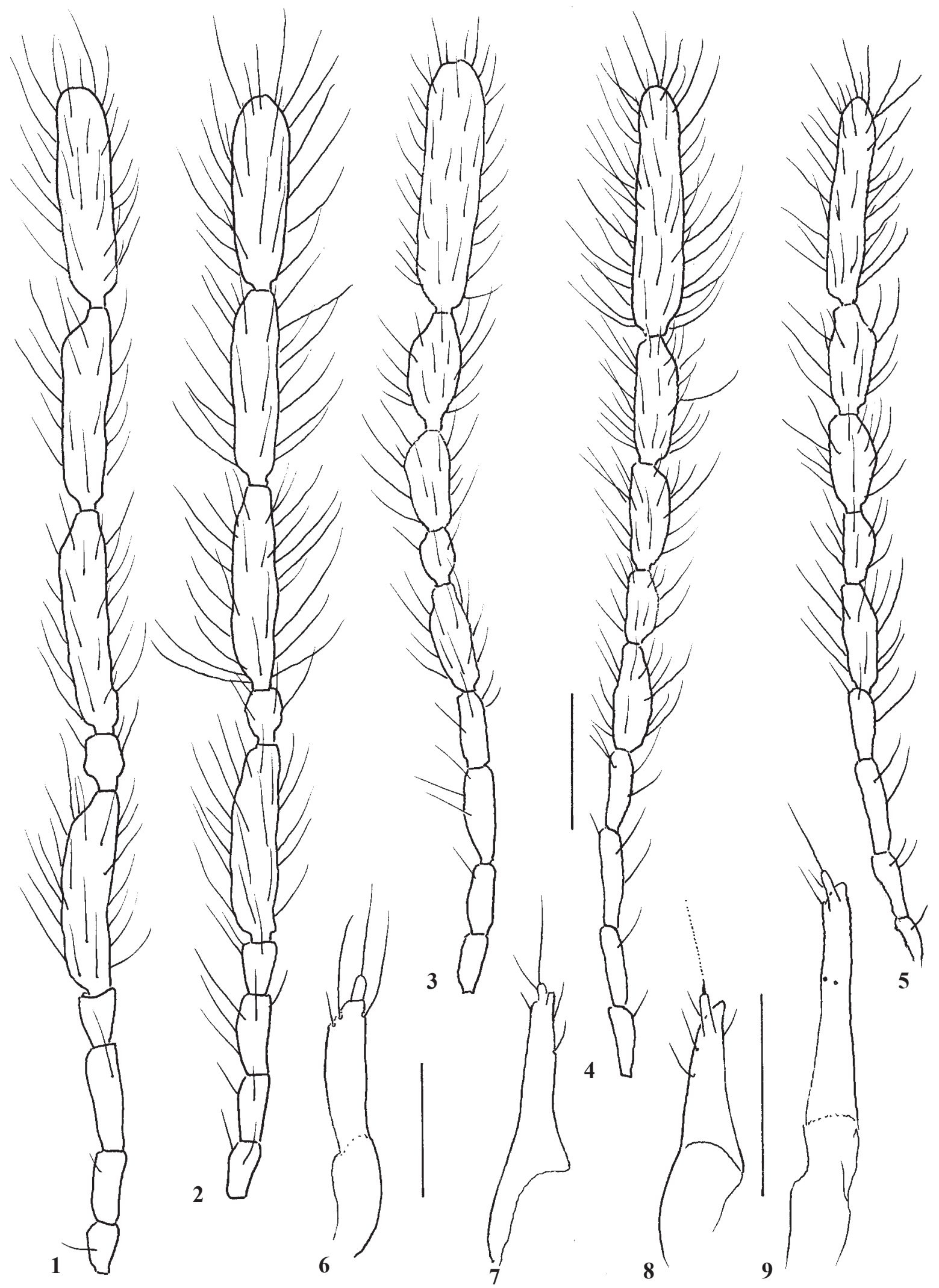

Figs 1-9. Scaphobaeocera spp.: $1-$ S. yunnana sp.n.; 2, $6-$ S. junlei sp.n.; 3, 7 - S. glabra sp.n.; 4, 8 - S. michaeli sp.n.; 5, $9-$ S. schuelkei sp.n.; 1-5 - antennomeres 3-11; 6-9- gonocoxite. Scale $=0.1 \mathrm{~mm}$.

Pис. 1-9. Scaphobaeocera spp.: $1-$ S. yunnana sp.n.; 2, $6-$ S. junlei sp.n.; 3, 7 - S. glabra sp.n.; 4, $8-$ S. michaeli sp.n.; 5, 9 S. schuelkei sp.n.; 1-5-3-11 членики антенны; 6-9- гонококситы. Масштаб = 0,1 мм. 
antennomeres light brown. Legs ochreous, tarsi lighter than tibiae or femora. Length/width rations of antennomeres as: III 17/8: IV 20/8: V 23/9: VI 16/10: VII 59/14: VIII 15/11: IX 60/13: X 58/15: XI 58/18 (Fig. 2). Pronotum and elytra barely iridescent, microsculpture indistinct at 100 times magnification. Pronotal punctation very fine and shallow. Tip of scutellum exposed. Elytra with sutural striae starting at basal margin, laterally pronotal lobe, parasutural striae indistinct. Elytral punctation slightly more distinct than pronotal punctation. Hypomera with fine line separating upper oblique section from larger lower section. Ventral side of thorax not microsculptured, appearing impunctate. Medio-anterior part of metaventrite convex, without mesal stria, impunctate on small area in middle. Medio-posterior part of metaventrite slightly impressed; punctation very dense and rather coarse, punctures to part larger than puncture interval on medioposterior area and on each side of middle, between mesocoxae and metacoxae. Submesocoxal lines parallel, with sparse, fine, not elongate punctures, submesocoxal areas about 0.02 $\mathrm{mm}$, as long as seventh of shortest intervals between them and metacoxae. Metanepisterna flat, $0.08-0.10 \mathrm{~mm}$ wide, slightly narrowed anteriad, with straight, deep suture. Tibiae straight. Abdomen with strigulate microsculpture.

Male characters. Protarsomeres 1 to 3 strongly enlarged, 1 about almost as wide as apices of tibiae, 2 and 3 slightly narrower than 1. Aedeagus (Figs 12-14) $0.58-0.63 \mathrm{~mm}$ long, with apical process much shorter than basal bulb, obliquely inflexed and blunt at apex. Apical side of basal bulb not prominent. Parameres wide, enlarged apically in lateral view, almost straight in dorsal view. Internal sac simple, without hook or denticle, flagellum convoluted.

Female characters. Protarsomeres not enlarged. Metaventrite densely punctate and pubescent on small apicomedian surface. Gonocoxite and gonostyle as Fig. 6.

ETYMOLOGY. The species epithet is a Chinese noun meaning fungi.

DIFFERENTIAL DIAGNOSIS. Only four described species of Scaphobaeocera (S. balkei Löbl, 2017, S. excensa Löbl, 2011, S. fujiana Löbl, 2003, and S. zdenae Löbl, 1992), have peculiar antennae with enlarged antennomere VII, and IX, X and XI, combined with conspicuously shortened antennomeres VI and VIII. This new species shares a narrow, convoluted flagellum with the New Guinean $S$. balkei. It may be readily distinguished from $S$. balkei by the antennomeres VII shorter than the antennomeres III to VI combined and about 4 times as long as wide, while the antennomeres VII are notably longer that III to VI and almost 6 times as long as wide in S. balkei. The male characters of the Himalayan $S$. zdenae are still unknown, the species may be nevertheless distinguished from $S$. junlei by the microsculptured and iridescent body and by the parallel-sided antennomeres VII and IX. The Philippine $S$. excensa has the antennomeres IV twice as long as the antennomeres III, and a quite distinctive aedeagus, with a long tapering apical process. The Chinese $S$. fujiana may be readily distinguished from these species by its smaller body-size, the apical part of the parameres abruptly widened and the flagellum bearing a tubercle in its middle section.

\section{Scaphobaeocera yunnana Löbl sp.n.}

Figs 1, 10-11.

MATERIAL EXAMINED. Holotype $\sigma^{7}$ : CHINA: Yunnan [CH07-14] Baoshan Pref., Gaoligong Shan, 33 km SE Tongchong,

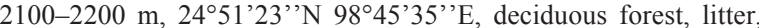
wood, fungi sifted, 31.V.2007, M. Schülke (MSPC).

Paratypes: $3 \sigma^{7}, 1 \%$, with the same data as the holotype (MSPC, MHNG).
DESCRIPTION. Length $1.40-1.52 \mathrm{~mm}$, width $0.85-$ $0.93 \mathrm{~mm}$, dorsoventral diameter $0.86-0.88 \mathrm{~mm}$. Head, pronotum, hypomera, mesoventrite, mesanepisterna and coxae very dark reddish-brown, elytra, metaventrite, metanepisterna blackish with reddish shine or black, abdomen blackish with light apical segments. Antennae light brown, with antennomere I to $\mathrm{V}$ yellowish. Femora and tibiae ochreous, tarsi lighter than tibiae. Length/width rations of antennomeres as: III 15/9: IV 21/8: V 30/9: VI 15/11: VII 61/15: VIII 16/12: IX 68/14: X 60/16: XI 65/16 (Fig. 1). Pronotum, elytra and ventral side of body not iridescent or elytra weakly iridescent. Pronotum not microsculptured, with punctation very fine and shallow. Tip of scutellum exposed. Elytra microsculptured, with sutural striae starting at basal margin, laterally pronotal lobe, parasutural striae absent. Elytral punctation slightly more distinct than pronotal punctation. Hypomera without distinct line separating upper oblique section from larger lower section. Ventral side of thorax not microsculptured. Lateral parts of metaventrite appearing impunctate. Medioanterior part of metaventrite convex, with mesal stria. Punctation on apicomedian area of metaventrite fine, with punctures mostly much smaller than puncture intervals and short pubescence. Medio-posterior part of metaventrite slightly impressed. Submesocoxal lines parallel, with sparse, fine, not elongate punctures, submesocoxal areas about $0.02 \mathrm{~mm}$, as long as seventh of shortest intervals between them and metacoxae. Metanepisterna flat, $0.06-0.07 \mathrm{~mm}$ wide, parallel-sided, with straight, deep suture. Tibiae straight. Abdomen with microsculpture strigulate, appearing absent from ventrite 1 .

Male characters. Protarsomeres 1 to 3 moderately enlarged, narrower than apices of tibiae. Aedeagus (Figs 10, 11) $0.44-0.46 \mathrm{~mm}$ long, with apical process about as long as basal bulb, obliquely inflexed and tapering. Apical side of basal bulb oblique. Parameres narrow in basal section, widened apically and with slightly sinuate ventral margins in lateral view, almost straight in dorsal view. Internal sac simple, without hook or denticle, flagellum sinuate, narrow.

Female characters. Protarsomeres not widened.

ETYMOLOGY. The species epithet is an adjective referring to Yunnan.

DIFFERENTIAL DIAGNOSIS. The aedeagal characters suggest relationships with $S$. fujiana, though the new species may be easily distinguished by the parameres gradually widened apicodorsally and by the flagellum lacking a mesal tubercle. This new species differs notably in external characters from the sympatric $S$. junlei by its antennomeres $\mathrm{V}$ twice as long as the antennomeres VI, the metaventrite having a mesal stria and much finer punctation, and the metanepisterna narrower and parallel-sided.

\section{Scaphobaeocera glabra Löbl sp.n.}

Figs 3, 7, 15-16.

MATERIAL EXAMINED. Holotype $\sigma^{r}$ : CHINA: Yunnan [CH07-14] Baoshan Pref., Gaoligong Shan, 33 km SE Tongchong, 2100-2200 m, 2451'23' 'N 9845'35' E, deciduous forest, litter, wood, fungi sifted, 31.V.2007, M. Schülke (MSPC).

Paratypes: $1+$ with the same data as the holotype (MHNG), 1 $\mathrm{O}^{7}$, labelled as the holotype but [CH07-13] $36 \mathrm{~km} \mathrm{SE} \mathrm{Tongchong,}$ $2200 \mathrm{~m}, 24^{\circ} 49^{\prime} 32^{\prime}$ 'N $98^{\circ} 46^{\prime} 06^{\prime}$ 'E, decid. forest, litter, wood, fungi sifted (MSPC), and 2 , with the same data but leg. A. Pütz (APPC, MHNG).

DESCRIPTION. Length $1.35-1.43 \mathrm{~mm}$, width $0.75-0.82$ $\mathrm{mm}$, dorsoventral diameter $0.78-0.85 \mathrm{~mm}$. Most of body very dark brown, hypomera and abdomen lighter, appendages light brown to ochreous. Length/width rations of antennomeres as: 


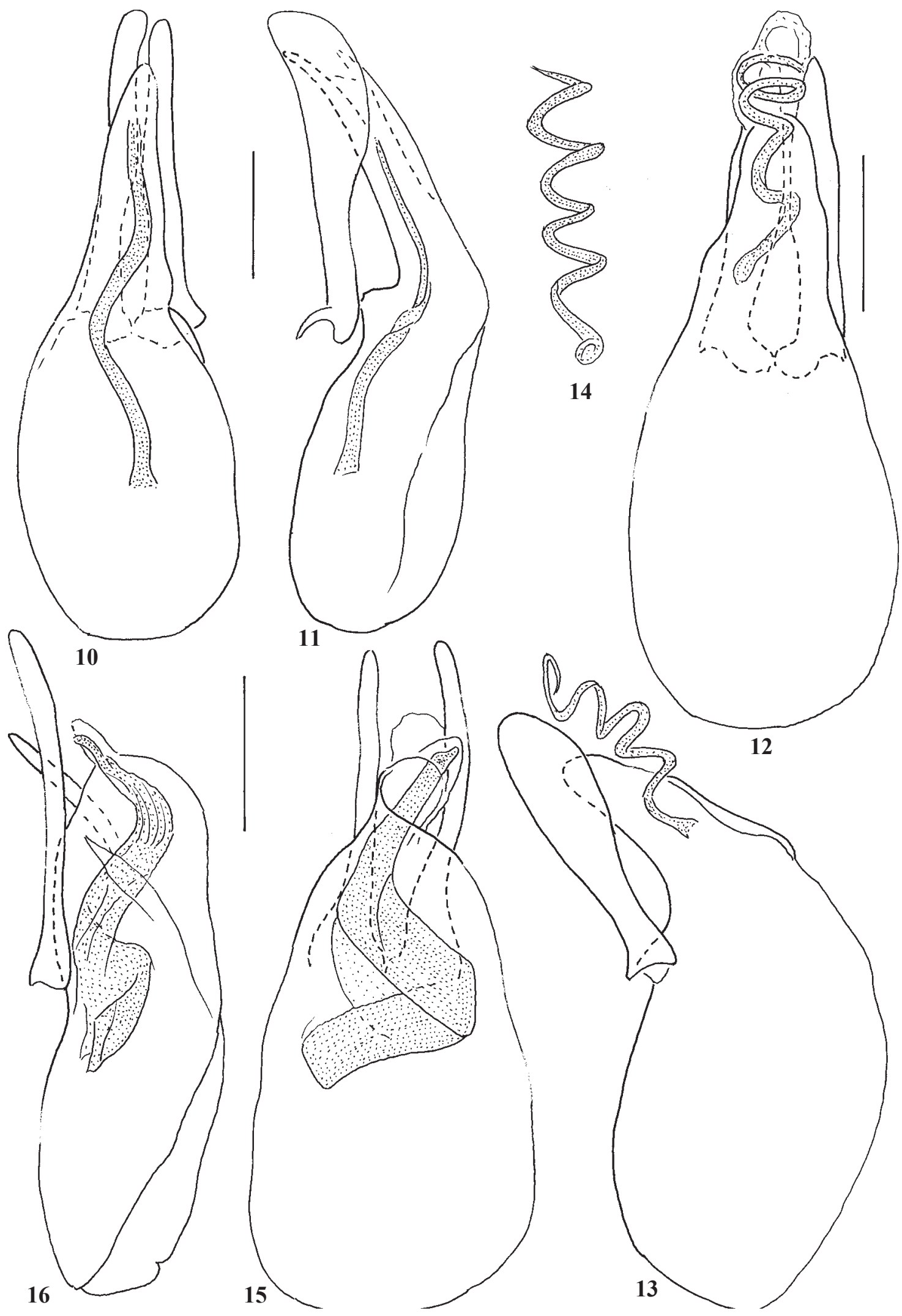

Figs 10-16. Scaphobaeocera spp.: 10-11 - S. yunnana sp.n.; 12-14 - S. junlei sp.n.; 15-16 - S. glabra sp.n.; 10-13, 15-16 aedeagus; 14 - flagellum; 10, 12, 15 - dorsal view; $11,13,16-$ lateral views. Scale $=0.1 \mathrm{~mm}$.

Рис. 10-16. Scaphobaeocera spp.: 10-11 - S. yunnana sp.n.; 12-14 - S. junlei sp.n.; 15-16 - S. glabra sp.n.; 10-13, 15-16 эдеагус; 14 - флагеллум; 10, 12, 15 - сверху; 11, 13, 16 - сбоку. Масштаб = 0,1 мм. 
III 18/8: IV 20/8: V 29/9: VI 23/8: VII 32/12: VIII 17/9: IX 30/ 14: X 35/16: XI 76/17 (Fig. 3). Pronotum and elytra not iridescent and not microsculptured. Pronotal punctation very fine and shallow. Apical part of scutellum exposed. Elytra with sutural striae starting at basal margin, laterally pronotal lobe, parasutural striae absent. Elytral punctation slightly coarser than pronotal punctation, punctures shallow, irregular, denser toward apices. Hypomera with distinct, posteriad shortened line separating upper oblique section from larger lower section. Ventral side of thorax not microsculptured. Lateral parts of metaventrite appearing impunctate. Median part of metaventrite convex, without mesal stria and not impressed apically, almost smooth in middle. Punctation laterad and posteriad middle area of metaventrite distinct, very dense, with punctures to part about as large as or larger than puncture intervals, pubescence short. Submesocoxal lines parallel, with sparse, fine, not elongate punctures, submesocoxal areas about 0.02 $\mathrm{mm}$, about as long as seventh of shortest intervals between them and metacoxae. Metanepisterna flat, $0.07-0.08 \mathrm{~mm}$ wide, almost parallel-sided, with straight, deep suture. Tibiae straight. Abdomen with ventrite 1 microsculptured in middle, not microsculptured on prevailing surface, following ventrites with punctulate microsculpture.

Male characters. Protarsomeres 1 to 3 slightly widened, much narrower than apices of tibiae. Aedeagus (Figs 15, 16) $0.48-0.51 \mathrm{~mm}$ long, with apical process much shorter than basal bulb, obliquely inflexed and blunt. Apical side of basal bulb convex. Parameres asymmetrical, left paramere distinctly sinuate in dorsal view, right paramere almost straight in dorsal view, both evenly narrow, somewhat bent in lateral view. Internal sac with broad flagellum folded in proximal section, bent in middle, narrowed and stronger sclerotized in apical section.

Female characters. Protarsomeres not narrowed. Gonocoxite and gonostyle as Fig. 7.

ETYMOLOGY. The species epithet is an adjective meaning glabrous.

DIFFERENTIAL DIAGNOSIS. Several species of Scaphobaeocera possess strongly elongate apical antennomeres, which are about as long as the antennomeres IX and X combined (S. abnormalis Löbl, 1981, S. antennalis Löbl, 1975, S. complicans Löbl, 2011, S. delicatula Löbl, 1971, S. dorsalis Löbl, 1980, S. gemina Löbl, 2017, S. japonica (Reitter, 1880), S. minutissima (Löbl, 1969), S. montivagans Löbl, 2011, S. palawana Löbl, 2011, S. ponapensis Löbl, 1981, S. remota Löbl, 1981, S. stephensoni Löbl, 1988, and $S$. watrousi Löbl, 2011). This new species may be easily distinguished from most of them, $S$. antennalis, $S$. delicatula, $S$. remota, and $S$. palawana excepted, by the broad flagellum forming a single loop, and it is unique in having the flat proximal part of the flagellum folded and apex of flagellum acute, in combination with asymmetrical, narrow parameres. The species differs from its congeners with similar antennae by the elytra lacking microsculpture and without parasutural striae, in combination with the lateral parts of the ventrite 1 lacking microsculpture and the apical ventrites bearing punctulate microsculpture.

\section{Scaphobaeocera michaeli Löbl sp.n.}

Figs 4, 8, 17-19.

MATERIAL EXAMINED. Holotype $\sigma^{7}$ : CHINA: Yunnan [CH07-11], Baoshan Pref., Gaoligong Shan, nr. Xiaoheishan N.R. $35 \mathrm{~km}$ SE Tengchong, $2110 \mathrm{~m}, 24^{\circ} 50^{\prime} 16^{\prime \prime} \mathrm{N}, 98^{\circ} 45^{\prime} 43^{\prime \prime} \mathrm{E}$, decid. forest, litter, sifted, 30.V.2007, M. Schülke (PCMS) MHNG)
Additional possibly conspecific material: 1 , CHINA: Yunnan [CH07-17], Baoshan Pref., mountain range $25 \mathrm{~km} \mathrm{~S}$ Tengchong, $1900 \mathrm{~m}, 24^{\circ} 48^{\prime} 26^{\prime}$ 'N, 98³2'03' 'E, dev. primary decid. forest, litter, fungi sifted, 2.VI.2007, M. Schülke (PCMS).

DESCRIPTION. Length $1.37-1.41 \mathrm{~mm}$, width $0.77-$ $0.81 \mathrm{~mm}$, dorsoventral diameter $0.83-0.87 \mathrm{~mm}$. Most of body, and femora dark brown or reddish-brown, pronotum somewhat darker than elytra, metaventrite as mesoventrite or darkened, antennae, tibiae, tarsi, and apical abdominal segments ochreous. Length/width rations of antennomeres as: III 21/7: IV 24/6: V 29/7: VI 23/7: VII 32/14: VIII 22/9: IX 32/ 12: X 38/13: XI 75/15 (Fig. 4). Pronotum not microsculptured, with punctation very fine and shallow. Apical part of scutellum exposed. Elytra with distinct strigulate microsculpture, not or barely iridescent, with sutural striae starting at basal margin, laterally pronotal lobe, parasutural striae present, hardly visible. Elytral punctation almost as fine as pronotal punctation, punctures well delimited, similar on entire discal surface. Hypomera with distinct, not shortened line separating upper oblique section from larger lower section. Ventral side of mesothorax not microsculptured. Lateral parts of metaventrite with strigulate microsculpture, very sparsely and very finely punctate. Median part of metaventrite flattened, without mesal stria and not impressed apically, smooth on minute middle area. Punctation laterad and posteriad smooth area of metaventrite distinct, very dense, with punctures to part about as large as or larger than puncture intervals, pubescence short. Submesocoxal lines convex, with sparse, fine, not elongate punctures, submesocoxal areas about $0.04 \mathrm{~mm}$, about as long as third of shortest intervals between them and metacoxae. Metanepisterna flat, $0.10 \mathrm{~mm}$ wide, parallel-sided, with deep, straight suture. Tibiae straight. Abdomen with strigulate microsculpture, distinct also on laterobasal areas of ventrite 1 .

Male characters. Protarsomeres 1 to 3 widened, narrower than apices of tibiae. Aedeagus (Figs 17-19) $0.36 \mathrm{~mm}$ long, with apical process much shorter than basal bulb, strongly inflexed and blunt. Apical side of basal bulb oblique. Parameres asymmetrical, sinuate and evenly narrow in dorsal view, somewhat bent and widened apically in lateral view. Internal sac with broad, sinuate flagellum becoming membranous apically.

Female characters. Protarsomeres not widened. Gonocoxite and gonostyle as Fig. 8.

ETYMOLOGY. The species is dedicated to its collector, Michael Schülke (Berlin).

DIFFERENTIAL DIAGNOSIS. The aedeagal characters of this new species suggest close relationships with $S$. glabra sp.n. They share asymmetrical parameres and broad flagellum not forming loops. S. michaeli sp.n. may be distinguished from S. glabra by the parameres widened apically and the apical process of median lobe much narrower and more inflexed at tip. It may be easily distinguished from $S$. glabra sp.n. by the microsculptured elytra and lateral parts of the metaventrite.

\section{Scaphobaeocera schuelkei Löbl sp.n.} Figs 5, 9, 20-21.

MATERIAL EXAMINED. Holotype $\sigma^{7}$ : CHINA: N-Yunnan [C2005-15] Nujiang Lisu Aut. Pref., Gongshan Co. Gaoligong Shan small creek valley $17 \mathrm{~km}$ N Gongshan / $27^{\circ} 54.41^{\prime} \mathrm{N}, 98^{\circ} 39.55^{\prime} \mathrm{E}$, $1525-1600 \mathrm{~m}$ along creek under stones/gravel /leaf litter, sifted, 20.VI.2005, M. Schülke [C2005-15] (MSPC).

PARATYPES: $1 \sigma^{7}$, CHINA: S-Shaanxi (Qinling Shan) pass on rd. Zhouzhi-Foping, 105 km SW Xi'an, N-slope, 1990 m, 

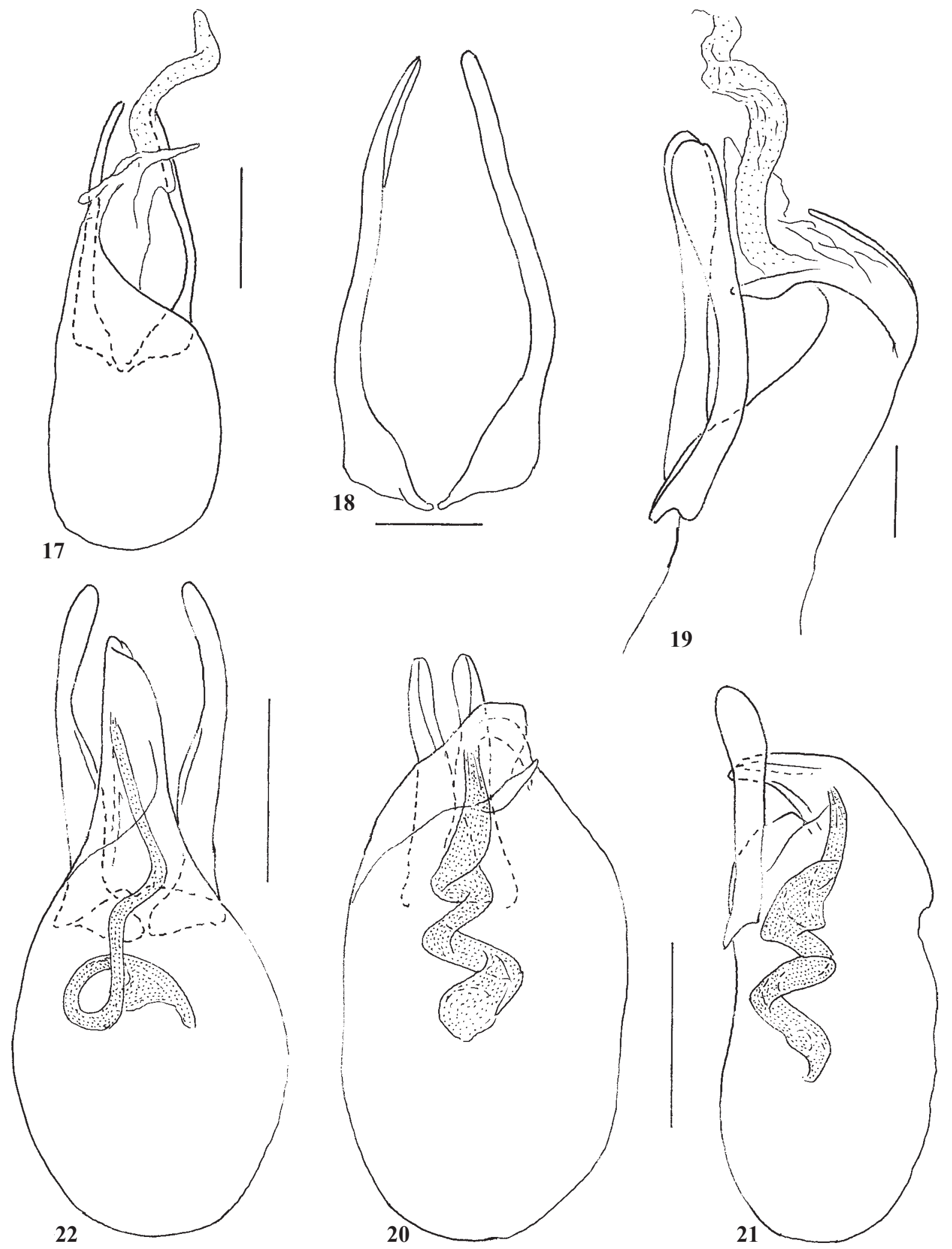

Figs 17-22. Scaphobaeocera spp.: 17-19-S. michaeli sp.n.; 20-21 - S. schuelkei sp.n.; $22-$ S. puetzi sp.n.; 17, 20-22 - aedeagus; 18 - parameres; 19 - aedeagus, without proximal part of basal bulb; 17, 20, 22 - dorsal view; 18 - ventral view; 19, 21 - lateral view. Scales: $17,22-0.1 \mathrm{~mm} ; 18-19-0.05 \mathrm{~mm} ; 20-21-0.2 \mathrm{~mm}$.

Рис. 17-22. Scaphobaeocera spp.: 17-19-S. michaeli sp.n.; 20-21 - S. schuelkei sp.n.; 22 - S. puetzi sp.n.; 17, 20-22 - эдеагус; 18 - парамеры; 19 - эдеагус без проксимальной части базальной луковицы; 17, 20, 22 - сверху; 18 - снизу; 19, 21 - сбоку. Масштаб: $17,22-0,1$ мм; 18-19-0,05 мм; 20-21-0,2 мм. 
$33^{\circ} 44^{\prime}$ N, $107^{\circ} 5^{\prime}$ leg. M. Schülke [C01-01] / 2./4.VII.2001, small creek valley, mixed deciduous forest, bamboo, small meadows, dead wood mushrooms (sifted) [C01-01] (MHNG); 1 , CHINA: Border Shaanxi - Sichuan (Daba Shan) pass $20 \mathrm{~km}$ SSE Zhenping, 1700-1800 m, 31 $44^{\circ} \mathrm{N}, 109^{\circ} 35^{\prime} \mathrm{E}, 12$.VII.2001, leg. M. Schülke [C01-07C9] / mixed forest. Small creek valley, moss, bank (sifted) $[\mathrm{CO} 1-07 \mathrm{C}](\mathrm{MHNG}) ; 1$ ㅇ, CHINA: S-Shaanxi (Daba Shan) $\mathrm{NW}$ pass $25 \mathrm{~km} \mathrm{NW}$ Zhenping, $32^{\circ} 01^{\prime} \mathrm{N}, 109^{\circ} 11^{\prime} \mathrm{E}, 2150 \mathrm{~m}$, 11.VII.2001, leg. M. Schülke [C01-09] / creek valley young coniferous forest, moss (sifted) [C01-09] (MSPC); 1 क, CHINA S-Shaanxi (Qinling Shan) pass on rd. Zhouzhi-Foping, $105 \mathrm{~km}$

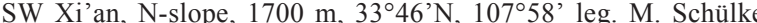
[C01-02] / 3.VII.2001, small creek valley, mixed deciduous forest, moss (sifted) [C01-02] (MSPC); 1 \% , CHINA: W-Hubei (Daba Shan) pass east of Mt. Da Shennonglia, $12 \mathrm{~km} \mathrm{NW}$ Muyuping, $31^{\circ} 30^{\prime} \mathrm{N} 110^{\circ} 21^{\prime} \mathrm{E}, 17 . \mathrm{VII} .2001$, leg. M. Schülke [C01-13C] creek valley, 1950-2050 m, mixed deciduous forest, moss, dead wood, mushrooms (sifted) [C01-13C] (MSPC); 1 +, CHINA: WHubei (Daba Shan) creek valley $8 \mathrm{~km} \mathrm{NW}$ Muyuping, $31^{\circ} 29^{\prime} \mathrm{N}$, $110^{\circ} 22^{\prime}$ E 1550-1650 m, 18.VII.2001, leg. M. Schülke [C0116A] / creek valley, deciduous forest, moss (sifted) [C01-16A] (MHNG).

Additional possibly conspecific material: $1 \sigma^{7}, \mathrm{CHINA}: \mathrm{Si}-$ chuan Prov., $22 \mathrm{~km}$ NE Baoxing, Dengchigou Monastery, 13.VI.2014, $1800 \mathrm{~m}, 30^{\circ} 32^{\prime} 08^{\prime}$ 'N $102^{\circ} 56^{\prime} 28^{\prime \prime} \mathrm{E} / \mathrm{sift} \mathrm{O}^{\top} 18$, secondary mixed forest with Cryptomeria and broadleaved trees, close to monastery, J. Hájek, J. Růžička leg. (NMPC) - a damaged specimen, most of antennae missing, internal sac partly extruded.

DESCRIPTION. Length 1.30-1.42 mm, width 0.68 $0.80 \mathrm{~mm}$, dorsoventral diameter $0.73-0.80 \mathrm{~mm}$. Most of body and femora uniformly dark reddish-brown, or pronotum darkened, blackish-brown, antennae, tibiae, tarsi, and apical abdominal segments lighter, ochreous. Length/width rations of antennomeres as: III 15/7: IV 20/7: V 28/7: VI 20/8: VII 30/11: VIII 20/10: IX 28/13: X 30/13: XI 62/11 (Fig. 5). Pronotum and elytra with or without strigulate microsculpture, not iridescent. Pronotal punctation very fine and shallow. Apical part of scutellum exposed. Elytra with sutural striae starting at basal margin, laterally pronotal lobe, parasutural striae hardly visible or obsolete. Elytral punctation coarser than pronotal punctation, punctures well delimited, irregular, sparser near bases. Hypomera with distinct but shortened line separating upper oblique section from larger lower section. Ventral side of thorax not microsculptured. Lateral parts of metaventrite with sparse and very fine punctation. Median part of metaventrite flattened, without mesal stria and not impressed apically, smooth on minute middle area. Punctation laterad and posteriad smooth area of metaventrite distinct, very dense, with punctures to part about as large as or larger than puncture intervals, pubescence short. Submesocoxal lines parallel, with sparse, fine, not elongate punctures, submesocoxal areas about $0.03-0.04 \mathrm{~mm}$, about as long as fourth or third of shortest intervals between them and metacoxae. Metanepisterna flat, $0.09 \mathrm{~mm}$ wide, parallelsided, with suture deep, straight except at rounded anterior angles. Tibiae straight. Abdomen with strigulate microsculpture, obsolete on laterobasal areas of ventrite 1.

Male characters. Protarsomeres 1 to 3 strongly widened, 1 about as wide as apices of tibiae. Aedeagus (Figs 20, 21) $0.42-0.62 \mathrm{~mm}$ long, with apical process very short, strongly inflexed and blunt. Apical side of basal bulb convex. Parameres symmetrical, widened in middle part in dorsal view, straight and evenly wide between bases and apical sections, near apices slightly widened and bent in lateral view. Internal sac with broad flagellum forming two loops.

Female characters. Protarsomeres not widened. Gonocoxite and gonostyle as Fig. 9.

ETYMOLOGY. This species is also named in honour of its collector, Michael Schülke (Berlin).
DIFFERENTIAL DIAGNOSIS. The aedeagal characters suggest close relationships of this new species with $S$. japoni$c a$. It may be distinguished from the latter by the parameres almost straight in lateral view and widened in middle part in dorsal view, and by the shorter and more inflexed apical process of median lobe [see Löbl, 1981]. The antennomeres XI are slightly longer than the combined length of the antennomeres IX and X in S. schuelkei sp.n., while in S. japonica they are slightly shorter than the combined antennomeres IX and $\mathrm{X}$. The pronotal and elytral microsculpture are absent from most specimens, and the size of the aedeagi is unusually variable in this new species.

\section{Scaphobaeocera puetzi Löbl sp.n.}

Figs 22-26.

MATERIAL EXAMINED. Holotype $\sigma^{7}$ : CHINA: Yunnan [CH07-11A], Baoshan Pref., Gaoligong Shan, nr. Xiaoheishan N.R., $35 \mathrm{~km}$ SE Tengchong, $2110 \mathrm{~m}, 24^{\circ} 50^{\prime} 16^{\prime}$ 'N, 98 $98^{\circ} 43^{\prime}$ 'E, decid. forest, fungi, sifted, 4.VI.2007, leg. A. Pütz (PCAP).

Paratypes: 3 \%, 2 \%, CHINA: Yunnan [CH07-24], Nujiang Lisu Aut. Pref., Gaoligong Shan, valley $18 \mathrm{~km}$ W Gongshan, $27^{\circ} 47^{\prime} 54^{\prime}$ 'N, $98^{\circ} 30^{\prime} 13^{\prime}$ 'E, $3020 \mathrm{~m}$, mixed forest, litter, moss, wood sifted, 7.VI.2007, leg. A. Pütz (PCAP, MHNG); $2 \sigma^{7}, 1$, same data but leg. M. Schülke (PCMS, MHNG); $3 \sigma^{7}, 3$, , CHINA: Yunnan [C2005-16], Nujiang Lisu Aut. Pref., Gongshan Co., Gaoligong Shan, side valley, 3000-3050 m, 2747'90'’N, 98³0'19' 'E /conif. forest with Rhododendron, broad leaved bushes, litter, moss, dead wood sifted along creek and snowfields, 21.VI.2005, M. Schülke [C2005-16] (PCMS, MHNG); $1 \sigma^{7}$, CHINA (Yunnan) Nujiang Lisu Aut. Pref., Gaoligong Shan, valley $18 \mathrm{~km} \mathrm{~W}$ Gongshan, 2747'54' $\mathrm{N}$, $98^{\circ} 30^{\prime} 13^{\prime}$ 'E, $3020 \mathrm{~m}$ (mixed forest, litter, moss, wood sifted) 7.VI.2007 D.W.Wrase [24] (MSPC).

DESCRIPTION. Length 1.21-1.50 mm, width $0.68-$ $0.78 \mathrm{~mm}$, dorsoventral diameter $0.68-0.81 \mathrm{~mm}$. Head and most of body black, apices of elytra and apical abdominal segments reddish-brown or ochreous, appendages ochreous, tarsi and antennae lighter than tibiae and femora. Length/width rations of antennomeres as: III 18/6: IV 18/6: V 22/7: VI 18/6: VII 23/9: VIII 16/10: IX 26/16: X 28/18: XI 38/18 (Fig. 25). Pronotum and elytra not microsculptured and not iridescent. Pronotal punctation very fine, punctures well delimited, dense. Scutellum concealed. Elytra with sutural striae starting at basal margin, laterally pronotal lobe, parasutural striae hardly visible or obsolete. Elytral punctation near bases similar to pronotal punctation, somewhat coarser on prevailing surfaces, consisting of well delimited punctures. Hypomeral striae or lines absent. Ventral side of thorax not microsculptured. Lateral parts of metaventrite with sparse and very fine punctation. Median part of metaventrite flat or weakly impressed, without mesal stria, smooth on prevailing surface, on apical part with irregular, conspicuously coarse punctures, surfaces delimiting laterally median surface distinctly punctate. Pubescence reduced. Submesocoxal lines parallel, with sparse, fine, not elongate punctures, submesocoxal areas about $0.02 \mathrm{~mm}$, about as long as fifth or sixth of shortest intervals between them and metacoxae. Metanepisterna flat, 0.08-0.09 $\mathrm{mm}$ wide, parallel-sided in posterior halves, with sutures deep, rounded in anterior halves. Tibiae straight. Abdomen with strigulate microsculpture, sometimes obsolete on ventrite 1 ; basal punctures elongate.

Male characters. Protarsomeres 1 to 3 distinctly widened, 1 narrower than apices of protibiae. Aedeagus (Figs 22-24) 0.38-0.44 mm long, with apical process long, moderately inflexed, tapering. Apical side of basal bulb concave. Parameres symmetrical, narrowed toward apical fourth and somewhat bent in dorsal view, oblique and widened 


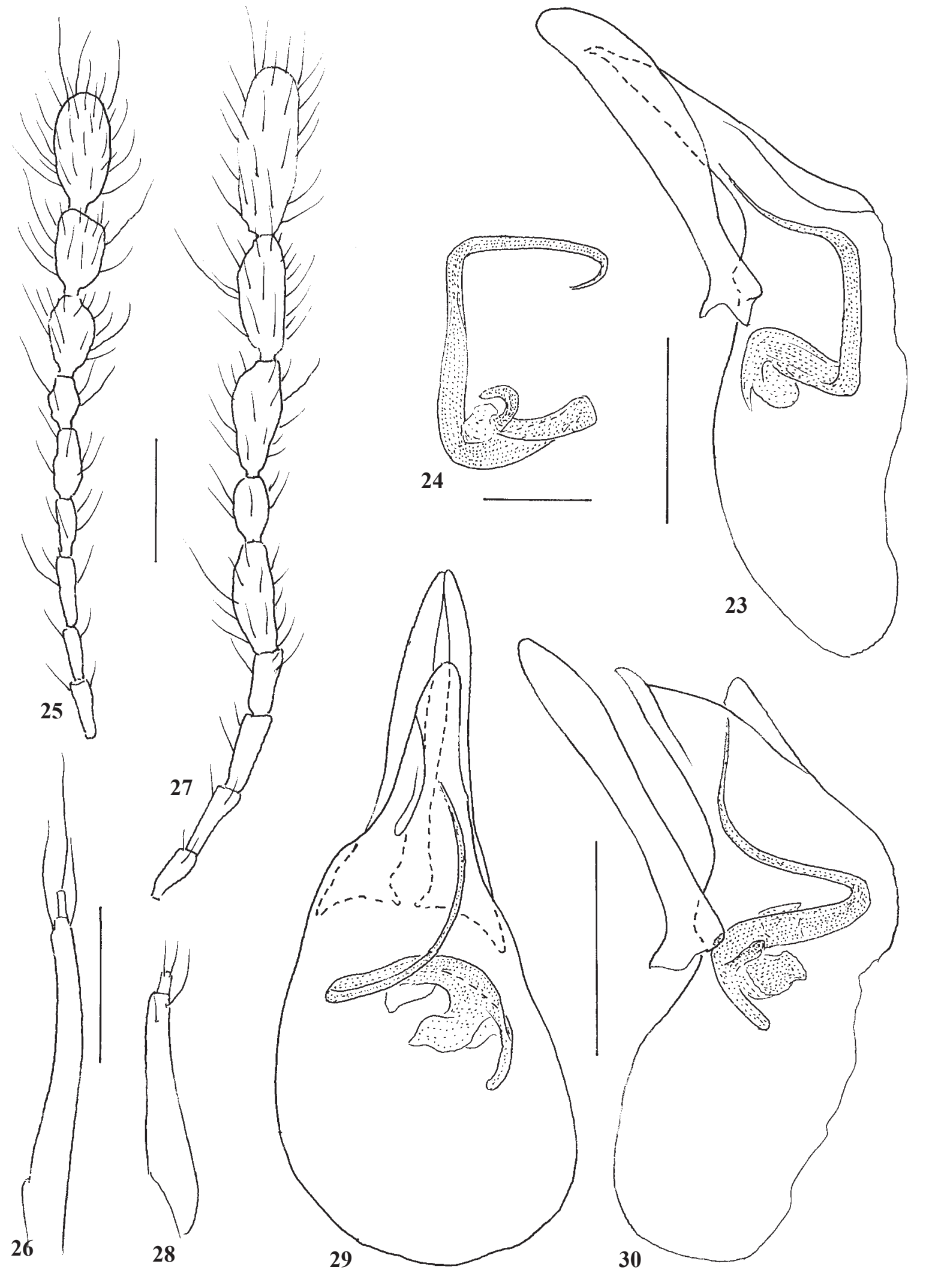

Figs 23-30. Scaphobaeocera spp.: 23-26 - S. puetzi sp.n.; 27-30 - S. glabripennis sp.n.; 23, 29-30 - aedeagus; 24 - flagellum; 25, 27 - antennomeres 3-11; 26, 28 - gonocoxite; 23,30 - lateral view; 29 - dorsal view. Scales: $23,25-23-0.1 \mathrm{~mm} ; 24-0.05 \mathrm{~mm}$

Рис. 23-30. Scaphobaeocera spp.: 23-26 - S. puetzi sp.n.; 27-30 - S. glabripennis sp.n.; 23, 29-30 - эдеагус; 24 - флагеллум; $25,27-3-11$ членики антенны; 26, 28 - гонококсит; 23, 30- сбоку; 29 - сверху. Масштаб: 23, 25-23-0,1 мм; $24-0,05$ мм. 
from bases to mid-length in lateral view. Internal sac with moderately widened base and basal hook, forming single loop.

Female characters. Protarsomeres not widened. Gonocoxite and gonostyle as Fig. 26.

ETYMOLOGY. This species is named in honour of one of its collectors, Andreas Pütz (Eisenhüttenstadt).

DIFFERENTIAL DIAGNOSIS. This species may be distinguished from its Chinese congeners by the overwhelmingly black body, short antennae, concealed scutellum and not microsculptured elytra, in combination. The aedeagal characters of $S$. puetzi sp.n. suggest relationships with $S$. lanka (Löbl, 1971), S. gagatum (Löbl, 1971), and S. siamense (Löbl, 1990), though the internal sac lacks a basal vesicle.

\section{Scaphobaeocera glabripennis Löbl sp.n.}

Figs 27-30.

MATERIAL EXAMINED. Holotype $0^{7}$ : CHINA: N Yunnan [C03-19A] Dali Bai Nat. Aut. Pref., Diancang Shan, 3 km W Dali old town pine forest at "Cloud Road" right upper chair lift station $25^{\circ} 41.1^{\prime} \mathrm{N} 100^{\circ} 06.8^{\prime} \mathrm{E}, 2650-2750 \mathrm{~m} /[\mathrm{C} 03-19 \mathrm{~A}]$ pine needles, moss (dry) in ditches, mushrooms, 30.VIII.2003, leg. M. Schülke (MSPC).

Paratypes: 4 O, 11 + ; CHINA: N Yunnan [C03-19A] Dali Bai Nat. Aut. Pref., Diancang Shan, $3 \mathrm{~km} \mathrm{~W}$ Dali old town pine forest at "Cloud Road" right upper chair lift station $25^{\circ} 41.1^{\prime} \mathrm{N} 100^{\circ} 06.8^{\prime} \mathrm{E}$, 2650-2750m / [C03-19A] pine needles, moss (dry) in ditches, mushrooms, 30.VIII.2003, leg. M. Schülke (MSPC, MHNG); $4 \mathrm{O}^{7}$, 5 ㅇ S Same but [C03-19B] pine needles, moss (dry) in ditches, mushrooms, traps, 1.IX.2003 (MSPC, MHNG); $1 \mathrm{O}^{7}, 7$ \%; Same bu [C03-19C] pine needles, moss (dry) in ditches, mushrooms, traps, 3.IX.2003 (MSPC, MHNG); 2 O. CHINA: N-Yunnan [C03-03] Lijiang Naxi Aut. Co., $3 \mathrm{~km}$ NW Yongsheng, $53 \mathrm{~km}$ WSW Lijiang, $26^{\circ} 41.8^{\prime} \mathrm{N}, 100^{\circ} 43.1^{\prime} \mathrm{E}, 1950-2000 \mathrm{~m}$, SE slope, secondary broadleaved forest, 14.VIII.2003, M. Schülke (MSPC); 1 ㅇ, CHINA: N Yunnan [C03-20] Dali Bai Nat. Aut. Pref., Diancang Shan, 4 km W Dali old town, $25^{\circ} 41.4^{\prime} \mathrm{N}, 100^{\circ} 06.7^{\prime} \mathrm{E}, 2900-3000 \mathrm{~m}$ E slope with devastated forest and old pine forest, mushrooms, 31.VIII.2003, leg. M. Schülke (MSPC); 2 O'; CHINA: N-Yunnan [C2005-11] Dal Bai Nat. Aut. Pref., Diancang Shan, $3 \mathrm{~km}$ W Dali old town, pine forest at "Cloud Road", $25^{\circ} 41.1^{\prime} \mathrm{N} 100^{\circ} 06,8^{\prime} \mathrm{E}, 17$.VII.2005, leg. M. Schülke (MSPC); 1 9 , CHINA: N Yunnan [CH07-03] Dali Ba

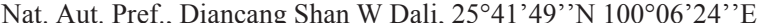
$2970 \mathrm{~m}$, sifted at rock edges and under small shrubs, 28.V.2007, M. Schülke (MSPC); 2 9 , CHINA (Yunnan) Dali Bai Nat. Aut. Pref., Diancang Shan W Dali, 2543'47' 'N 100'06'32''E 3016 m (moist escarpment, litter sifted) 28.V.2007 D.W.Wrase [04] (MSPC); 1 웅 CHINA (Yunnan) Nujiang Lisu Aut. Pref., creek valley $3 \mathrm{~km} \mathrm{SE}$

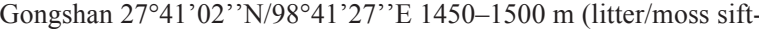
ed) 5.VI.2007 D.W.Wrase [20] (MSPC); $10^{7}$, CHINA: Yunnan [C2005-16], Nujiang Lisu Aut. Pref., Gongshan Co., Gaoligong

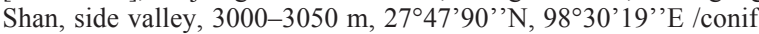
forest with Rhododendron, broad leaved bushes, litter, moss, dead wood sifted along creek and snowfields, 21.VI.2005, M. Schülke [C2005-16] (MHNG).

DESCRIPTION. Length $1.12-1.33 \mathrm{~mm}$, width 0.61 $0.81 \mathrm{~mm}$, dorsoventral diameter $0.64-0.83 \mathrm{~mm}$. Head and most of body light, reddish-brown. Apical abdominal segments lighter, appendages as most of body or slightly lighter. Length/width rations of antennomeres as: III 18/8: IV 23/7: V 27/9: VI 22/9: VII 35/13: VIII 20/12: IX 36/15: X 38/15: XI 53/19 (Fig. 27). Pronotum and elytra not microsculptured and not iridescent. Pronotal punctation very fine, punctures well delimited, dense. Scutellum almost concealed, with hardly visible minute tip. Elytra with sutural striae starting at basal margin, laterally pronotal lobe, parasutural striae obsolete. Elytral punctation near bases similar to pronotal punctation, irregular and to part coarser on prevailing surfaces, consisting of variably well delimited punctures. Hypomeral striae or lines absent. Ventral side of thorax not microsculp- tured. Lateral parts of metaventrite with sparse and very fine punctation. Median part of metaventrite weakly convex, without mesal stria, smooth on anterior surface, with irregular, dense and coarse punctures on apical part. Pubescence short. Submesocoxal lines convex, with sparse, fine, not elongate punctures, submesocoxal areas about $0.03 \mathrm{~mm}$, about as long as third of shortest intervals between them and metacoxae. Metanepisterna flat, $0.06-0.07 \mathrm{~mm}$ wide, parallel-sided, with deep, straight sutures. Tibiae straight. Ventrite 1 lacking obvious microsculpture, with basal punctures hardly elongate. Following ventrites with hardly visible strigulate microsculpture.

Male characters. Protarsomeres weakly widened, much narrower than apices of tibiae. Aedeagus (Figs 29, 30) $0.26-0.32 \mathrm{~mm}$ long, with apical process fairly short, moderately inflexed, with blunt tip. Apical side of basal bulb concave. Parameres symmetrical, oblique and slightly widened subapically in lateral view. Internal sac with robust, anchor-like base, flagellum very narrow, forming single loop.

Female characters. Protarsomeres not widened. Gonocoxite and gonostyle as Fig. 28.

ETYMOLOGY. The species epithet is a Latin adjective meaning smooth elytra.

DIFFERENTIAL DIAGNOSIS. The aedeagal characters suggest relationships with $S$. dispar Löbl, 1980 from Taiwan, S. smetanai Löbl, 1981 from Japan, and S. timida Löbl, 1984 widely distributed in the Himalayas and recorded from the Chinese province Jiangxi. These three species possess distinct elytral microsculpture and dorsum of body at least partially iridescent. [see Löbl 1981, 1984]. The aedeagus of S. glabripennis sp.n. differs drastically from that of $S$. timida and $S$. dispar by the much shorter apical process of the median lobe, not extended posterior level of parameral tips, and from that of $S$. smetanai by the parameres weakly widened posteriad.

\section{Scaphobaeocera difficilis Löbl, 1979}

MATERIAL EXAMINED. $1 \sigma^{7}$, Yunnan, Dali Bai Auton. Pref.,

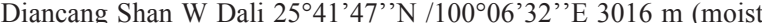
escarpment, litter sifted) 28.V.2007 D.W.Wrase [04] (MSPC); $1 \mathrm{O}^{7}$, Yunnan [CH07-02\} Dali Bai Auton. Pref., Diancang Shan W Dali $25^{\circ} 41^{\prime} 20^{\prime \prime} \mathrm{N}, 100^{\circ} 06^{\prime} 12^{\prime \prime} \mathrm{E}, 3160 \mathrm{~m}$ small creek valley, litter and debris sifted, 27.V.2007, M. Schülke (MSPC); $10^{7}$, Yunnan [CH0708\} Dali Bai Auton. Pref., Diancang Shan 43 km NW Dali, 3078 m, $25^{\circ} 59^{\prime} 35^{\prime \prime} \mathrm{N}, 99^{\circ} 52^{\prime} 06^{\prime}$ ' E, W pass, Rhodod., oaks, bamboo, sifted, 29.V.2007, M. Schülke (MSPC); $1 \mathrm{O}^{7}$, Yunnan 2800-3000m 25.12N 100.24E Weibaoshan Mts, 29-39/6.92 Vít Kubáň leg. (MHNG); 1 $\sigma^{7}$, Yunnan 2500-2700m 25.58N 100.21E Jizu Shan 6-10.7.1994 Vít Kubáň leg. (NMPC); $1 \sigma^{7}$, W-Hubei (Daba Shan) pass east of Mt. Da Shennonglia, $12 \mathrm{~km}$ NW Muyuping, $31^{\circ} 30^{\prime} \mathrm{N} 110^{\circ} 21^{\prime} \mathrm{E}$, 1950 m, 16.VII.2001, leg. M. Schülke [C01-13] / dry creek valley, mixed deciduous forest, dead wood, mushrooms (sifted) [C01-13] (MSPC); $1 \mathrm{O}^{7}$, S-Shaanxi (Daba Shan) mountain range $\mathrm{N}$ pass 22 km NW Zhenping, N slope, $32^{\circ} 01^{\prime} \mathrm{N} 109^{\circ} 21^{\prime} \mathrm{E}, 2400 \mathrm{~m}, 13$.VII.2001, leg. M. Schülke [C01-11]/ mixed forest (Pinus, Salix and other deciduous trees) (sifted) [C01-11] (MSPC); $10^{7}, 2$ ㅇ, W-Sichuan Ya'an Prefecture, Tianquan Co., W Erlang Shan Pass / 2780 m, 21.VI.1999 29.51.27N, 102.15.47E leg. A. Pütz sifted (APPC): 1 $\sigma^{7}$, Jianxi Prov., Linggangshan Mts. Shuangxikou (river valley) 24.ii.2011 $26^{\circ} 31.4^{\prime} \mathrm{N} 114^{\circ} 11.3^{\circ} \mathrm{E} 411 \mathrm{~m}$, Fikáček, Hájek, Jia \& Song / sifting moist leaf litter in sparse forest along stony river (NMPC); $1 \bigcirc^{7}$, Sichuan Prov., Wolong Natural Nature Reserve, Namasi vill., $2145 \mathrm{~m}, 23 . \mathrm{VI} .2014,31^{\circ} 01^{\prime} 28^{\prime \prime} \mathrm{N}, 103^{\circ} 09^{\prime} 40^{\prime \prime} \mathrm{E}$, sift $\mathrm{O}^{\top} 25$, shrub in close stream valley at base of rocks, above small water dam, side valley, J. Hájek \& J. Rủžička leg. (NMPC).

COMMENTS. This species is known from Pakistan, India, Nepal, Thailand and was reported from the Hubei Prefecture [Löbl, 1999]. 
Scaphobaeocera dorsalis Löbl, 1980

MATERIAL EXAMINED. $1 \mathrm{O}^{7}, 2$, Guangxi A.R., 11.iv.2013 ca. $1.5 \mathrm{~km}$ SSE Longsheng, Hot Spring, Dashankou (rotten longs with fungi, bamboo) $25^{\circ} 53.4^{\prime} \mathrm{N}, 110^{\circ} 12.7^{\prime} \mathrm{E}, 395 \mathrm{~m}$ M. Fikáček, J. Hájek, J. Růžička (NMPC).

COMMENTS. The species was described from Taiwan and subsequently reported from India, Nepal, Thailand, Japan, South Korea, and the Chinese provinces Sichuan and Yunnan [Löbl, 1980, 1984, 1990, 1999; Hoshina et al. 2009; Hoshina, 2011]. Unlike in other specimens, the male from Guangxi has unusually short antennomere XI, only about 1.5 times as long as the antennomere $\mathrm{X}$. The aedeagus is distinctive, the sole species possessing a similar aedeagus is the Philippine S. minutissima (Löbl, 1969)

\section{Scaphobaeocera cognata Löbl, 1984}

MATERIAL EXAMINED. $1 \sigma^{7}$, S. Sichuan, S Xichang, Mt. Luboji, 2300-2500 m, 16-24.7.1996, S. Kurbatov (MHNG); $10^{7}$, Yunnan, Nujiang Lisu Aut. Pref., Salween side valley $5 \mathrm{~km} \mathrm{~S}$ Fugong, road SS $228 \mathrm{~km}$ 223, creek bank, litter sifted, 8.VI.2007, D.W.Wrase [25] (MSPC).

COMMENTS. This species was described from North India and subsequently recorded from Nepal [Löbl, 1992] and the Chinese Provinces Shaanxi, Sichuan, and Yunnan [Löbl, 1999].

\section{Scaphobaeocera nuda Löbl, 1979}

MATERIAL EXAMINED. 1 ○', Yunnan [CH07-18] Baoshan Pref., mountain range $22 \mathrm{~km} \mathrm{~S}$ Tengchong, $1750 \mathrm{~m}, 24^{\circ} 49^{\prime} 29^{\prime \prime} \mathrm{N}$ 98 $29^{\prime} 27^{\prime}$ 'E, second. forest, litter, dead wood sifted, 2.VI.2007, M Schülke (MSPC); $10^{7}$, Yunnan [CH07-28] Nujiang Lisu Aut. Pref., Gaoligong Shan, side valley $19 \mathrm{~km}$ NW Liuku, $25^{\circ} 59^{\prime} 02^{\prime}$ 'N 98 42 '23' 'E, $2730 \mathrm{~m}$, devast. prim. forest, litter sifted, 9.VI.2007, leg. A. Pütz (MHNG); $10^{7}$, Y Ynnan [CH07-37] Tianmu Shan, pass $25 \mathrm{~km}$ NNW Linan, $620-820 \mathrm{~m}, 30^{\circ} 25^{\prime} 40^{\prime}$ 'N, 119 $35^{\prime} 30^{\prime \prime} \mathrm{E}$, creek valley with bamboo and mixed forest, litter, sifted, 16.VI.2007 M. Schülke (MHNG); $1 \mathrm{O}^{\top}$, Yunnan [CH07-35] Dali Bai Auton. Pref., Wuling Shan, 9 km SW Weishan, 2450-2500 m, 2510'14'’N, W slope, $100^{\circ} 14^{\prime} 22^{\prime \prime}$ E, oaks and pines, sifted, 13.VI.2007, M. Schülke (MSPC); $20^{7}$, Yunnan [CH07-11] Baoshan Pref., Gaoligong Shan, nr. Xiaoheishan N.R., $35 \mathrm{~km} \mathrm{SE}$ Tengchong, $2110 \mathrm{~m}, 24^{\circ} 50^{\prime} 16^{\prime}$ 'N, 98 $45^{\prime} 43^{\prime}$ 'E, decid. forest, litter, sifted, 30.V.2007, M. Schülke (MSPC, MHNG); 1 O', Yunnan [CH07-15] Baoshan Pref., Gaoligong Shan, $29 \mathrm{~km}$ ESE Tengchong, $24^{\circ} 55^{\prime} 37^{\prime} ' \mathrm{~N}, 98^{\circ} 45^{\prime} 04^{\prime \prime} \mathrm{E}$, $2350 \mathrm{~m}$, decid. forest, wood litter sifted, 1.VI.2007. M. Schülke (MSPC); $1 \sigma^{7}$, N-Yunnan [C03-03] Lijiang Naxi Aut. Co., $3 \mathrm{~km}$ NW Yongsheng, $53 \mathrm{~km}$ WSW Lijiang, $26^{\circ} 41.8^{\prime} \mathrm{N}, 100^{\circ} 43.1^{\prime} \mathrm{E}$ 1950-2000 m, SE slope, secondary broadleaved forest, 14.VIII.2003, M. Schülke (MSPC); 1 Oో, Yunnan [CH07-19] Dehong Dai Aut. Pref., mountain range, $31 \mathrm{~km} \mathrm{E}$ Luxi, $2280 \mathrm{~m}, 24^{\circ} 29^{\prime} 31^{\prime \prime} \mathrm{N}$, $98^{\circ} 52^{\prime} 58^{\prime}$ 'E, second. pine forest with old decid. trees, litter sifted, 3.VI.2007, A. Pütz (APPC).

COMMENTS. This species was described from South India [Löbl, 1979] and subsequently reported from North India, Nepal and Thailand [Löbl, 1984, 1990, 1992]. It is new to China.

\section{Scaphobaeocera spinigera Löbl, 1979}

MATERIAL EXAMINED. $1 \sigma^{7}$, N-Yunnan [C03-05] Zhongdiang Co., 46 km SSE Zhongdiang, $27^{\circ} 27.0^{\prime}$ N, $99^{\circ} 54.7^{\prime} \mathrm{E} 3050$ $3100 \mathrm{~m}$, creek valley, secondary mixed forest, bamboo, mushrooms, 17.VIII.2003, leg. M. Schülke (PCMS); $2 O^{7}, 1$ ㅇ, Yunnan [CH0724] Nujiang Lisu Aut. Pref., Gaoligong Shan, valley $18 \mathrm{~km} \mathrm{~W}$ Gongshan, $3020 \mathrm{~m}, 27^{\circ} 47^{\prime} 54^{\prime}$ 'N $98^{\circ} 30^{\prime} 13^{\prime}$ 'E, mixed forest, litter, moss, wood, sifted, 7.VI.2007, M. Schülke (MSPC, MHNG).

COMMENTS. This species was described from South India and subsequently reported from Pakistan, Nepal, Thailand and China. The published Chinese records are from Sichuan and Hong Kong [Löbl, 1999].

\section{Scaphoxium intermedium Löbl, 1984}

MATERIEL EXAMINED. $1 \sigma^{7}$, Guangxi A.R., 11.iv.2013 ca. $1.5 \mathrm{~km} \mathrm{SSE}$ of Longsheng Hot Spring, Dashankou (rotten logs with fungi; bamboo) $25^{\circ} 53.4^{\mathrm{N}} \mathrm{N}, 110^{\circ} 12.7^{\prime} \mathrm{E}, 395 \mathrm{~m}$, M. Fikáček, J. Hájek, J. Růžička leg. (NMPC); 1 ○', 1 9, Zhejiang [CH07-37] Tianmu Shan, pass $25 \mathrm{~km}$ NNW Linan, $620-820 \mathrm{~m}, 30^{\circ} 25^{\prime} 40^{\prime \prime} \mathrm{N}$, $119^{\circ} 35^{\prime} 30^{\prime \prime} \mathrm{E}$, creek valley with bamboo and mixed forest, litter, sifted, 16.VI.2007, A. Pütz (APPC, MHNG); 1 †, Yunnan [CH0718], Baoshan Pref., mountain range $22 \mathrm{~km} \mathrm{~S}$ Tengchong, $1750 \mathrm{~m}$, $24^{\circ} 49^{\prime} 29^{\prime}$ 'N, $98^{\circ} 29^{\prime} 27^{\prime \prime} \mathrm{E}$, second. forest, litter, dead wood sifted, 2.VI.2007, leg. A. Pütz (APPC); 1 O $^{\top}$, Hainan Isl. Limushan Mts., mountains above forest. Admin. Centre $19^{\circ} 10.5-10.9^{\prime} \mathrm{N} 109^{\circ} 44-$ 45'E 650-900 m; 6.v.2011, Fikáček / sifting - small accumulation of moist leaf litter along and on the trail in secondary forest partly with Cyanthea and bamboo (NMPC); 1 + Z Zhejiang [CH07-36] Tianmu Shan N.R., way to peak of immortals, $30^{\circ} 20^{\prime} 34^{\prime \prime}$ N, $119^{\circ} 25^{\prime} 51^{\prime}$ 'E, $1100-1200 \mathrm{~m}$, prim. mixed forest, litter moss, sifted, 15.VI.2007, M. Schülke (MSPC).

COMMENTS. This species was described from northern India [Löbl, 1984] and subsequently reported from Thailand and the Chinese Provinces Anhui and Yunnan [Löbl, 1999, 2003]. Thus, the records from Zhejiang, Guangxi and Hainan extend its known range.

Toxidium curtilineatum Champion, 1927

MATERIEL EXAMINED. $2 \sigma^{7}, 2$, Guangxi A.R., 11.iv.2013 ca. $1.5 \mathrm{~km}$ SSE of Longsheng Hot Spring, Dashankou (rotten logs with fungi; bamboo) $25^{\circ} 53.4^{\prime} \mathrm{N}, 110^{\circ} 12.7^{\prime} \mathrm{E}, 395 \mathrm{~m}$, M. Fikáček, J. Hájek, J. Růžička leg. (NMPC, MHNG); $1 O^{7}, 1$, Guangxi A.R., 11-14.iv.2013 Longsheng Hot Spring, forested river valley wet rocks) $25^{\circ} 53.6^{\prime} \mathrm{N}, 110^{\circ} 12.4^{\circ} \mathrm{E} 360 \mathrm{~m} \mathrm{M}$. Fikáček, J. Hájek, J. Růžička leg. (NMPC, MHNG).

COMMENTS. This species was known only from North India and Nepal [Löbl, 1999]. New to China.

\section{Toxidium robustum Pic, 1930}

MATERIEL EXAMINED. 1 \%", S-Yunnan (Xishuangbanna) $20 \mathrm{~km}$ NW Jinghong Man Dian (NNNR) / N22 ${ }^{\circ} 07.80^{\prime}$, E1000 $40.05,730 \mathrm{~m}, 15 . \mathrm{VI} .2008$, EKL, forest, leg. A. Weigel (NMEC); $1 \mathrm{O}^{7}, 3$, , Yunnan [CH07-11], Baoshan Pref., Gaoligong Shan, nr. Xiaoheishan N.R., $35 \mathrm{~km}$ SE Tengchong, $2110 \mathrm{~m}, 24^{\circ}$ $50^{\prime} 16^{\prime}$ 'N, $98^{\circ} 45^{\prime} 43^{\prime}$ 'E, decid. forest, litter, sifted, 30.V.2007, leg. A. Pütz (APPC, MHNG); 1 9 , Yunnan [CH07-19], Dehung Dai Aut. Pref., mountain range $31 \mathrm{~km}$ E Luxi, $2280 \mathrm{~m}, 24^{\circ} 29^{\prime} 31^{\prime}$ 'N $98^{\circ} 52^{\prime} 58^{\prime}$ 'E, second. pine forest with old decid. trees, litter sifted, 3.VI.2007, M. Schülke (MSPC); 1 \%, Yunnan [CH07-13], Baoshan Pref., Gaoligong Shan, E pass, $36 \mathrm{~km}$ SE Tengchong, $2200 \mathrm{~m}$, $24^{\circ} 49^{\prime} 32^{\prime}$ 'N, $98^{\circ} 46^{\prime} 06^{\prime}$ 'E, decid. forest, litter, wood, fungi sifted, 31.V.2007, M. Schülke (MHNG).

COMMENTS. This species was described from Myanmar and subsequently reported from Thailand [Löbl, 1990]. New to China.

ACKNOWLEDGEMENTS. The material studied comes from collections made by Andreas Pütz (Eisenhüttenstadt), Michael Schülke, David W. Wrase (both Berlin), Andreas Weigel (Wernburg) and Jiří Hájek and his colleagues from the National Museum in Prague. I thank all these colleagues and friends, as well as Matthias Hartmann (Erfurt), for having submitted the collections.

\section{References}

Hoshina H. 2011 New record of Scaphobaeocera dorsalis (Coleoptera, Staphylinidae, Scaphidiinae) from Japan // Elytra N.S. Vol.1. No.2. P.196

Hoshina H., Park S.-J., Ahn K.-J. 2009. Korean species of the genus Scaphobaeocera Csiki (Coleoptera: Staphylinidae: Scaphidiinae) in Korea // Entomological Research. Vol.39. P.326-329. 
Leschen R.A.B., Löbl I. 2005. Phylogeny and classification of Scaphisomatini Staphylinidae: Scaphidiinae with notes on mycophagy, termitophily, and functional morphology // Coleopterists Society Monographs. Vol.3. P.1-63.

Löbl I. 1979. Die Scaphidiidae (Coleoptera) Südindiens // Revue suisse de zoologie. T.86. Fasc.1. P.77-129.

Löbl I. 1980. Beitrag zur Kenntnis der Scaphidiidae (Coleoptera) Taiwans // Revue suisse de zoologie. T.87. Fasc.1. P.91-123.

Löbl I. 1981. Über die japanische Arten der Gattungen Scaphobaeocera Csiki und Scaphoxium Löbl (Col., Scaphidiidae) // Mitteilunger der Schweizerischen entomologischen Gesellschaft. Vol.54. No.1. P.229-244.

Löbl I. 1984. Les Scaphidiidae (Coleoptera) du nord-est de l'Inde et du Bhoutan I // Revue suisse de zoologie. T.91. Fasc.1. P.57107.
Löbl I. 1990. Review of the Scaphidiidae (Coleoptera) of Thailand // Revue suisse de zoologie. T.97. Fasc.3. P.505-621.

Löbl I. 1992. The Scaphidiidae (Coleoptera) of the Nepal Himalaya // Revue suisse de zoologie. T.99. Fasc.3. P.471-627.

Löbl I. 1997. Catalogue of the Scaphidiinae (Coleoptera: Staphylinidae) // Instrumenta biodiversitatis. Vol.1. P.xx + 190 pp.

Löbl I. 1999. A review of the Scaphidiinae (Coleoptera: Staphylinidae) of the People's Republic of China, I // Revue suisse de zoologie. T.106. Fasc.3. P.691-744.

Löbl I. 2003. A supplement to the knowledge of the Scaphidiines of China (Coleoptera: Staphylininae)// Mitteilungen der münchener entomologischen Gesellschatf. Vol.93. No.1. P.61-76.

Newton A.F. Jr., Stephenson S.L. 1990. A beetle/slime mold assemblage from northern India (Coleoptera; Myxomycetes) // Oriental Insects. Vol.24. P.197-218. 